Jurnal Riset Manajemen Sains Indonesia (JRMSI) | Vol 12, No. 2, 2021 e-ISSN: 2301-8313

http://doi.org/10.21009/JRMSI

DOI: doi.org/10.21009/JRMSI.012.2.06

\title{
EFISIENSI KINERJA KEUANGAN SEKTOR PERBANKAN INDONESIA DI MASA PANDEMI COVID-19
}

\author{
Erlinda Sholihah \\ Magister Manajemen Universitas Muhammadiyah Surakarta \\ Email: erlindasholihah@gmail.com
}

\begin{abstract}
ABSTRAK
Penelitian ini bertujuan untuk menganalisis efisiensi kinerja keuangan sektor perbankan Indonesia di masa pandemi covid-19 dengan memakai pendekatan Data Envelopment Analysis (DEA). Data yang digunakan adalah data sekunder yang berwujud dokumen financial statements dan annual report perbankan umum konvensional dan syariah yang didapat dari laman resmi www.idx.co.id dan www.ojk.go.id. Populasi dalam penelitian ini adalah seluruh perusahaan perbankan di Indonesia yang terdiri atas Bank Umum Konvensional dan Bank Umum Syariah. Teknik sampling yang digunakan adalah teknik purposive sampling dengan sampel sebanyak 31 Bank Umum Konvensional dan 13 Bank Umum Syariah. Metode pengukuran efisiensi yang dipakai adalah pengujian non parametrik Data Envelopment Analysis (DEA) dengan pendekatan intermediasi dan profit. Variabel input yang dipilih mencakup modal, aktiva tetap, dana pihak ketiga (DPK) dan biaya operasional. Sedangkan variabel output mencakup kredit atau pembiayaan dan laba. Hasil penelitian menunjukkan bahwa rata-rata tingkat efisiensi sektor perbankan baik Bank Umum Konvensional ataupun Bank Umum Syariah menghadapi penurunan yang substansial di masa pandemi covid-19.
\end{abstract}

Kata kunci: Efisiensi, Sektor Perbankan Indonesia, Data Envelopment Analysis, Covid-19 
Jurnal Riset Manajemen Sains Indonesia (JRMSI) | Vol 12, No. 2, 2021 e-ISSN: 2301-8313 http://doi.org/10.21009/JRMSI

\section{PENDAHULUAN}

Covid-19 pertama kali diidentifikasi di negara Cina pada Desember 2019, tetapi virus telah menyebar dengan cepat ke seluruh dunia (Hanoatubun, 2020). Mulai 20 Mei 2020, jumlah infeksi virus corona yang dikonfirmasi di seluruh dunia mendekati 5 juta di lebih dari 200 negara dan wilayah, dengan lebih dari 90\% dari kasus yang dilaporkan saat ini berada di luar Cina. Pandemi covid-19 yang sedang berlangsung tidak hanya mewakili publik di seluruh dunia darurat kesehatan, tetapi juga telah menimbulkan biaya ekonomi yang besar dan berjangkauan luas secara global (Zheng dan Zhang, 2020). Berdasarkan pengamatan pada situasi saat ini di mana negara Indonesia terlebih dunia secara global dipukul oleh pandemi covid-19 yang terlihat jelas menyebabkan perubahan pada segi ekonomi, gaya hidup dan adanya kebijakan pembatasan-pembatasan yang telah diberikan kepada masyarakat Indonesia. Sehingga Penyebaran virus itu sendiri dan langkah-langkah pencegahan untuk menguranginya menjadi sebab utama terhentinya aktivitas produksi dan konsumsi (Arianto, 2021).

Mewabahnya pandemi covid-19 di Indonesia saat ini berimbas pada hampir seluruh sektor kehidupan, baik dari segi ekonomi, politik, sosial hingga budaya. Begitupun yang dialami oleh salah satu sektor ekonomi yang merupakan jantung perekonomian suatu negara, ialah sektor perbankan (Adeabah dan Andoh, 2020). Saat ini sektor perbankan mengalami tantangan yang besar akibat pandemi covid-19. Situasi ini memiliki pengaruh yang amat mencemaskan bagi industri sektor perbankan (Ningsih dan Mahfudz, 2020). Sehingga berbagai upaya kebijakan dibuat oleh perbankan agar dapat bertahan di saat darurat pandemi covid-19 ini. Adapun upaya kebijakan yang dibuat demi menekan imbas dari dahsyatnya pandemi covid-19 ini adalah adanya Kebijakan Stimulus Perekonomian Nasional POJK No.11/POJK.03/2020 yang dikeluarkan pemerintah melalui Otoritas Jasa Keuangan. Adapun tujuan diterbitkannya regulasi ini adalah untuk mengelola kestabilan sistem keuangan dan perbankan (www.ojk.go.id). Dengan stimulus tersebut diharapkan perekonomian Indonesia semakin membaik dan pulih kembali agar dapat meningkatkan efisiensi kinerja keuangan sektor perbankan di masa pandemi covid-19 ini (Albanjari dan Kurniawan, 2020; Azhari dan Wahyudi, 2020).

Pengukuran efisiensi perbankan menjadi sangat penting saat ini, terutama di tengah situasi pandemi covid-19 ini. Karena efisiensi kinerja perbankan menjadi salah satu tolak ukur kinerja yang melandasi keseluruhan kinerja sebuah perusahaan yang merujuk pada 
Jurnal Riset Manajemen Sains Indonesia (JRMSI) | Vol 12, No. 2, 2021 e-ISSN: 2301-8313 http://doi.org/10.21009/JRMSI

memaksimalkan output sedemikian rupa atas pemanfaatan sumber daya input yang ada. Efisiensi bank didefinisikan sebagai perbedaan antara kuantitas yang diamati dari variabel input dan output sehubungan dengan kuantitas optimal dari variabel input dan output (Alam, 2013; Awaluddin et al., 2019; Othman et al., 2016). Bank dinyatakan efisien apabila mencapai nilai maksimum satu dibandingkan dengan bank yang tidak efisien, yang dapat turun ke level nol (Himmawan dan Firdausi, 2021). Demikian pula sektor perbankan harus bertanggung jawab atas keseluruhan kinerjanya yang di tunjukkan dalam annual report perusahaan sebagai alat untuk menilai prestasi perusahaan selama satu tahun (Evandri Notalin dan Asnaini, 2021).

Selain itu, kebutuhan pengukuran efisiensi sektor perbankan juga tersebar di berbagai pemangku kepentingan, baik dari regulator, manajemen bank, pemegang saham hingga konsumen atau nasabah bank. Berdasarkan sudut pandang regulator, penting untuk mengukur efisiensi sektor perbankan guna menilai kemungkinan adanya gagal bayar karena bank merupakan sumber dana dalam ekonomi dan membentuk produktivitas ekonomi. Sementara para pemegang saham juga merasa khawatir tentang pengembalian yang dihasilkan oleh bank. Selain itu, para nasabah juga akan memperhatikan kualitas layanan dan harga produk yang diperdagangkan oleh bank. Sehingga manajemen bank perlu memperkirakan dan menciptakan efisiensi untuk menyusun strategi agar dapat bertahan dalam lingkungan yang kompetitif (Roy, 2014).

Pendekatan pengukuran efisiensi perbankan selain menggunakan perbandingan parameter indeks kinerja perbankan dan rasio keuangan, terdapat beberapa teknik lain diantaranya adalah pendekatan parametrik dan non parametrik (Ngo dan Le, 2019). Mengenai pendekatan parametrik terdiri dari Distribution Free Approach (DFA), Thick Frontier Approach (TFA) dan Stochastic Frontier Approach (SFA), sementara non parametrik berupa pendekatan Data Envelopment Analysis (DEA) (Awaluddin et al., 2019). Hasil pengukuran efisiensi perbankan akan tepat jika memakai pendekatan parametrik atau non parametrik. Sebab dalam analisisnya kedua teknik tersebut memiliki kemampuan untuk melibatkan beragam input dan output (Cabrera-Suárez dan V. Pérez-Rodríguez, 2020). Selain itu, adanya keragaman variabel juga tidak menjadi persoalan, karena sifatnya yang lebih bebas dan dapat melingkupi berbagai variabel yang lebih besar daripada metode pendekatan lainnya (Evandri Notalin dan Asnaini, 2021; Himmawan dan Firdausi, 2021). 
Jurnal Riset Manajemen Sains Indonesia (JRMSI) | Vol 12, No. 2, 2021 e-ISSN: 2301-8313 http://doi.org/10.21009/JRMSI

Adapun pengukuran efisiensi yang akan dipakai dalam penelitian ini adalah metode Data Envelopment Analysis (DEA). Karena adanya berbagai keutamaan yang dimiliki metode ini diantaranya adalah tidak memerlukan hipotesis kerangka fungsi produksi, karakteristik efisiensi yang dinilai berciri teknis dan tak ekonomis serta hasil nilai efisiensi berciri relatif atau berlaku dalam lingkup sekelompok Unit Kegiatan Ekonomi (UKE) yang diperbandingkan semata (Arrawatia et al., 2015; Li et al., 2021; Sufian, 2011).

Kinerja sektor perbankan dan lembaga keuangan lainnya semakin menarik perhatian para peneliti untuk dikaji lebih dalam, terkhusus dalam penilaian efisiensi kinerja keuangan sektor perbankan (Zhao et al., 2021). Beberapa peneliti sebelumnya telah membahas mengenai efisiensi perbankan di berbagai negara, diantaranya Sufian (2011) di Korea, Roy (2014) di India, Zenebe Lema (2017) di Ethiopia, Eyceyurt Batir et al. (2017) di Turki, Henriques et al. (2018) di Brazil, Puteh et al. (2018) di Indonesia dan Neves et al. (2020) di Eropa. Selain itu, beberapa peneliti telah mengkaji tentang efisiensi perbankan di masa krisis dan pasca krisis, yaitu Andrieș dan Ursu (2016) yang menyatakan bahwa krisis memiliki dampak yang positif dan signifikan terhadap inefisiensi bank komersial di Eropa. Adapun Anagnostopoulos et al. (2020) menemukan bahwa pada masa pasca krisis, bank konvensional lebih efisien dibandingkan bank syariah di wilayah MENA. Sedangkan hasil penelitian yang dilakukan oleh Rahmi dan Putri (2019) menunjukkan adanya peningkatan rata-rata dalam tingkat efisiensi perbankan syariah di Indonesia selama tahun 2007-2009, artinya bahwa kinerja perbankan syariah telah meningkat semasa krisis global.

Sementara literatur yang ada tentang efisiensi sektor perbankan di masa pandemi covid-19 saat ini masih terbatas, dikarenakan pandemi covid-19 saat ini masih terjadi dan masih banyaknya penelitian yang berlangsung. Sebuah studi terbaru yang dilakukan oleh Ningsih dan Mahfudz (2020) membuktikan bahwa sejak Desember hingga Maret 2020 semua bank syariah di Indonesia mengalami guncangan dalam fungsi intermediasinya yang mengarah pada penurunan penghimpunan dana dan pembiayaan. Selanjutnya, dalam penelitian Himmawan dan Firdausi (2021) menunjukkan bahwa Bank Umum Syariah memiliki efisiensi dan stabilitas yang tinggi di masa pandemi covid-19, yaitu Bank BRI Syariah, Bank Muamalat, Bank Victoria Syariah, Bank BPD NTB Syariah dan Bank BTPN Syariah menunjukkan tingkat efisiensi yang tinggi tetapi stabilitas rendah. Bank Syariah Mandiri, Bank BNI Syariah, Bank BCA Syariah dan Bank Mega Syariah menunjukkan tingkat efisiensi yang rendah namun stabilitas tinggi. 
Jurnal Riset Manajemen Sains Indonesia (JRMSI) | Vol 12, No. 2, 2021 e-ISSN: 2301-8313 http://doi.org/10.21009/JRMSI

Peran intermediasi sektor perbankan menuntut bank untuk dapat memediasi antara unit surplus dan defisit, sehingga kemungkinan besar sektor perbankan akan menghadapi fase tersulit di masa pandemi covid-19 ini. Walaupun seluruh transaksi saat ini dapat dipermudah dengan sistem online, namun imbas dari pandemi covid-19 pada sektor perbankan akan lebih sulit dalam meningkatkan investasi dan pendanaan. Berkaitan dengan kondisi tersebut, maka pengukuran efisiensi kinerja keuangan sektor perbankan akan menjadi sangat urgen. Sebab efisiensi dapat mencerminkan kinerja suatu perusahaan dan dipandang sebagai faktor bagi pemangku kepentingan dalam merumuskan kebijakan strategis yang rasional untuk mengurangi adanya tingkat risiko operasional perbankan. Mengingat pandemi covid-19 masih berlangsung di Indonesia dan berdampak pada industri keuangan, penelitian ini didorong oleh keinginan untuk menganalisa lebih dalam mengenai seberapa baik sektor perbankan di Indonesia akan bertahan di masa pandemi covid-19 ini berdasarkan analisis pengukuran efisiensi.

\section{TELAAH PUSTAKA}

Pada prinsipnya, sistem operasional bank konvensional dan bank syariah memiliki perbedaan (Kamarudin et al., 2016). Dalam mengoperasikan bisnisnya, bank konvensional menghimpun dana dari masyarakat yang berbentuk tabungan, deposito, giro, kemudian menyalurkannya kepada pihak yang membutuhkan dalam bentuk kredit (Dara, 2017). Adanya simpanan dalam bentuk tabungan dan giro tersebut masyarakat dapat melakukan pengiriman dana dengan memakai cek dan alat pembayaran giral bahkan ikut serta dalam kegiatan kliring. Dimana hal tersebut merupakan tugas dan peran bank konvensional secara umum. Suatu bank konvensional dapat membentuk Unit Usaha Syariah (UUS) untuk membuka transaksi kegiatan perbankan syariah, namun operasional dan seluruh laporan keuangannya terpisah dari laporan keuangan bank konvensional (Ningsih dan Mahfudz, 2020; Rahmi dan Putri, 2019).

Berasaskan pada UU No. 21 tahun 2008 mengenai Perbankan Syariah, Bank Umum Syariah adalah salah satu bentuk dari perbankan nasional yang melandaskan sistem operasionalnya sesuai prinsip syariat Islam (Awaluddin et al., 2019; Mulazid, 2017). Sistem operasional Bank Syariah berasaskan pada prinsip syariah, yaitu adanya akad yang berlandaskan pada prinsip Islam antara pihak bank dengan pihak nasabah baik saat 
Jurnal Riset Manajemen Sains Indonesia (JRMSI) | Vol 12, No. 2, 2021 e-ISSN: 2301-8313 http://doi.org/10.21009/JRMSI

menyimpan dana ataupun transaksi pembiayaan hingga kegiatan bisnis lainnya yang dianggap sah berdasarkan nilai-nilai syariah Islam (Himmawan dan Firdausi, 2021; Rahmi dan Putri, 2019; Tahliani, 2020). Selain itu, istilah lain dari Bank Syariah adalah Islamic banking atau interest fee banking, yang berarti bahwa sistem perbankan yang dalam kegiatan operasionalnya tidak memberlakukan adanya bunga (riba), spekulasi (maisir) dan ketidakjelasaan (gharar) (Kamarudin et al., 2016, 2017; Puspitasari et al., 2018).

Efisiensi merupakan suatu konsep pencapaian hasil dengan penggunaan sumber daya secara optimal atau bentuk perbandingan antara jumlah yang dihasilkan (output) dengan jumlah yang dipergunakan (input) (Puteh et al., 2018; Rahmi dan Putri, 2019; Titko et al., 2014). Adapun Mulyadi (2020) mendefinisikan efisiensi sebagai segala sesuatu yang mengacu pada kesesuaian pemakaian sumber daya atas keperluan dan kapasitas tanpa adanya pemborosan. Dalam studi efisiensi keuangan, efisiensi dianggap sebagai ukuran yang mencerminkan perbedaan dari output maksimum yang dapat dicapai untuk tingkat input tertentu (Abdul-Wahab dan Haron, 2017). Farrell (1957) (dalam Himmawan dan Firdausi, 2021: 19) menyebutkan bahwa konsep efisiensi perbankan terdiri atas efisiensi alokatif dan efisiensi teknis. Efisiensi alokatif menjelaskan kemampuan perusahaan dalam menentukan input yang optimal untuk mewujudkan besarnya output yang dituju. Sementara efisiensi teknis menjelaskan keberhasilan perusahaan dalam memanfaatkan input yang dimiliki untuk memaksimumkan output yang dihasilkan.

Secara teoritis, terdapat beberapa pendekatan dalam mengukur efisiensi perbankan, yaitu pendekatan profit, pendekatan intermediasi dan pendekatan produksi (Mulyadi, 2020). Pendekatan profit menjelaskan kedudukan bank sebagai lembaga penghasil profit atau laba. Adapun pendekatan intermediasi menggambarkan fungsi bank sebagai biro perantara antara pihak surplus dengan pihak defisit. Sedangkan pendekatan produksi mendeskripsikan peran bank sebagai unit usaha yang menghasilkan output berupa jasa keuangan (Abdul-Wahab dan Haron, 2017; Dara, 2017).

Bisnis perbankan tentu berbeda dengan industri lainnya. Perbankan sebagai perusahaan yang beroperasi di bidang keuangan mempunyai perbedaan variabel output dan input dari industri atau perusahaan yang beroperasi di sektor riil (Ikra et al., 2021; Yilmaz dan Güneş, 2015). Oleh sebab itu, pengukuran efisiensi perbankan perlu didahului dengan pengenalan variabel input dan output dalam aktivitas bisnisnya (Puteh et al., 2018). Adapun input dan output yang dipakai dalam penelitian ini meliputi, input berupa modal, aktiva tetap, 
Jurnal Riset Manajemen Sains Indonesia (JRMSI) | Vol 12, No. 2, 2021 e-ISSN: 2301-8313 http://doi.org/10.21009/JRMSI

dana pihak ketiga (DPK) dan biaya operasional. Sementara output mencakup kredit atau pembiayaan dan laba.

Data Envelopment Analysis (DEA) adalah salah satu metode yang paling populer untuk diterapkan dalam studi pengukuran efisiensi perusahaan (Titko et al., 2014). Data Envelopment Analysis (DEA) merupakan aplikasi program linier untuk mengevaluasi efisiensi atau kinerja unit dengan keseluruhan unit yang diteliti. Dengan kata lain, merupakan suatu teknik yang membantu untuk mengidentifikasi kinerja perusahaan di sepanjang keberagaman dimensi agar menghasilkan batas produksi yang diinginkan (Abdul-Wahab dan Haron, 2017; Syairozi dan Handayati, 2017). DEA telah digunakan sebagai pengukuran kinerja kuantitatif dan analitis yang hebat untuk mengukur efisiensi perusahaan di hampir setiap industri di seluruh dunia sejak 1978, yang dikenalkan pertama kalinya oleh Charnes, Cooper dan Rhodes (Dell'Atti et al., 2015). Dengan menggunakan DEA, informasi efisiensi setiap unit kegiatan ekonomi (UKE) tersedia dan dengan demikian dapat mengidentifikasi perusahaan dengan praktik yang terbaik. Sehingga perusahaan yang teridentifikasi menjadi tolok ukur bagi perusahaan lain yang tidak efisien (Neves et al., 2020; Zhao et al., 2021).

DEA memiliki dua model yaitu Constant Return to Scale (CRS) dan Variable Return to Scale (VRS) (Himmawan dan Firdausi, 2021; Řepková, 2015). Dalam asumsi CRS menyatakan bahwa adanya kenaikan input senilai x kali, maka output juga akan naik yakni x kali. Sedangkan anggapan VRS menyatakan bahwa adanya tambahan input yakni x kali tak akan menyebabkan kenaikan output yakni x kali, akan mampu menjadi lebih kecil ataupun bahkan lebih besar (Henriques et al., 2018). Adapun rasio penilaian efisiensi antara 0 hingga 1. Bank dinyatakan efisien, bila mempunyai rasio yang mengarah pada nilai 1 ataupun $100 \%$, kebalikannya bila mengarah pada nilai 0 memperlihatkan efisiensi bank yang kian rendah. Sehingga dengan pengukuran DEA, tiap bank mampu menetapkan bobot nilainya masingmasing serta menanggung pembobotan yang telah ditentukan untuk menciptakan ukuran kinerja yang terbaik (Himmawan dan Firdausi, 2021; Mulyadi, 2020).

\section{METODE PENELITIAN}

\section{Data, Populasi dan Sampel}

Data yang disajikan pada studi ini berupa data sekunder, yakni data yang disajikan berwujud angka ataupun data kualitatif yang diangkakan, berupa data financial statement serta annual report Bank Umum Konvensional yang terdaftar di Bursa Efek Indonesia dan 
Jurnal Riset Manajemen Sains Indonesia (JRMSI) | Vol 12, No. 2, 2021 e-ISSN: 2301-8313 http://doi.org/10.21009/JRMSI

Bank Umum Syariah yang terdaftar di Otoritas Jasa Keuangan. Data sekunder ini didapat dalam wujud data eksternal berupa dokumen financial statements dan annual report perbankan umum konvensional dan syariah dari tahun 2019-2020 yang didapat dari laman Www.idx.co.id dan www.ojk.go.id.

Populasi dalam penelitian ini adalah seluruh perusahaan perbankan di Indonesia yang terdiri atas Bank Umum Konvensional dan Bank Umum Syariah. Adapun Bank Umum Konvensional yang terdaftar di BEI tahun 2019-2020 sebanyak 42 bank, sedangkan Bank Umum Syariah yang terdaftar di OJK sebanyak 14 bank. Teknik sampling yang digunakan adalah teknik purposive sampling. Berikut adalah sampel perusahaan yang digunakan dalam penelitian ini:

Tabel 1. Jumlah Sampel Perusahaan

\begin{tabular}{lcc}
\hline \multicolumn{1}{c}{ Kriteria } & Jumlah & Jumlah \\
\hline Bank Umum Konvensional dan Syariah yang terdaftar di BEI dan OJK dan & 42 & 14 \\
mempublikasikan laporan keuangannya di situs resmi tahun 2019-2020 & & \\
$\begin{array}{l}\text { Perbankan yang tidak mempublikasikan data laporan keuangan secara } \\
\text { lengkap dan teratur selama periode 2019-2020 }\end{array}$ & $(2)$ & $(0)$ \\
$\begin{array}{l}\text { Perbankan yang memiliki nilai negatif pada variabel input dan output dalam } \\
\text { laporan keuangan }\end{array}$ & $(9)$ & $(1)$ \\
\hline Jumlah sampel digunakan & 31 & 13 \\
Jumlah pengamatan (2 tahun) & 62 & 26 \\
\hline Sumber: data diolah, 2021 & &
\end{tabular}

\section{Definisi Operasional Variabel}

Penentuan variabel dalam proses pengukuran tingkat efisiensi sektor perbankan pada studi ini ialah dengan menggunakan pendekatan intermediasi dan profit. Karena kedua pendekatan ini dianggap dapat saling melengkapi antara peran bank sebagai lembaga perantara dan penghasil profit atau laba. Berikut input dan output yang digunakan meliputi:

Variabel input mencakup modal, aktiva tetap, dana pihak ketiga (dpk) dan biaya operasional. Modal merupakan jumlah ekuitas bank yang meliputi modal disetor, tambahan modal, modal sumbangan dan laba ditahan pada akhir periode. Aktiva tetap adalah nilai buku aktiva tetap dan inventaris pada akhir periode. Dana pihak ketiga yang diterima bank berupa giro, tabungan, deposito, sertifikat deposito dan surat berharga lainnya yang dikeluarkan bank 
Jurnal Riset Manajemen Sains Indonesia (JRMSI) | Vol 12, No. 2, 2021 e-ISSN: 2301-8313 http://doi.org/10.21009/JRMSI

pada akhir periode. Sedangkan biaya operasional yakni jumlah keseluruhan dari biaya operasional yang menjadi beban bank selama suatu periode tertentu yang mencakup biaya bunga, biaya administrasi serta umum, biaya tenaga kerja, beban penyisihan aset produktif serta biaya operasional lainnya.

Sedangkan variabel output mencakup kredit atau pembiayaan dan laba bersih. Kredit atau pembiayaan ialah total kredit yang diberikan bank setelah dikurangi penyisihannya pada suatu periode tertentu. Adapun laba bank merupakan laba bersih yang dihasilkan bank setelah dikurangi pajak dalam suatu periode tertentu.

\section{Metode Analisis}

Analisis terhadap kinerja efisiensi sektor perbankan pada penelitian ini menggunakan Data Envelopment Analysis (DEA) yang merupakan pendekatan statistik non parametrik untuk mengukur kinerja efisiensi perbankan. Adapun teknik perhitungannya dengan menggunakan software maxDEA yang mencakup data input dan output perusahaan. DEA memiliki karakteristik yang berbeda dari konsep efisiensi lazimnya. Keunggulan karakteristik DEA tersebut adalah efisiensi yang ditakar sifatnya teknis bukan ekonomis, selain itu angka efisiensi yang didapat sifatnya relatif dan hanya berlaku pada cakupan golongan unit yang dibandingkan tersebut (Evandri Notalin dan Asnaini, 2021; Rahmi dan Putri, 2019).

Adapun model yang dapat diaplikasikan dalam pengukuran efisiensi menggunakan metode DEA ialah Constant Return to Scale (CRS) dan Variable Return to Scale (VRS) (Alhassan dan Ohene-Asare, 2016). Model CRS mengasumsikan bahwa perubahan nilai pada input juga sebanding dengan perubahan outputnya. Sebaliknya, model VRS mengasumsikan bahwa perubahan output tidak sebanding dengan perubahan input, output yang dihasilkan mungkin lebih kecil atau lebih besar dari inputnya (Himmawan dan Firdausi, 2021; Miftahurrohman, 2017). Sehingga model yang dipilih untuk diaplikasikan pada penelitian ini ialah model Variable Return to Scale (VRS). Dikarenakan adanya tambahan input yakni x kali tak akan menyebabkan kenaikan output yakni x kali, akan mampu menjadi lebih kecil ataupun bahkan lebih besar.

\section{HASIL DAN PEMBAHASAN}

Hasil Uji Efisiensi 
Jurnal Riset Manajemen Sains Indonesia (JRMSI) | Vol 12, No. 2, 2021 e-ISSN: 2301-8313 http://doi.org/10.21009/JRMSI

Berikut hasil perhitungan efisiensi sektor perbankan dengan menggunakan software maxDEA yang ditunjukkan pada tabel di bawah ini:

Tabel 2. Hasil Perhitungan Efisiensi Bank Umum Konvensional

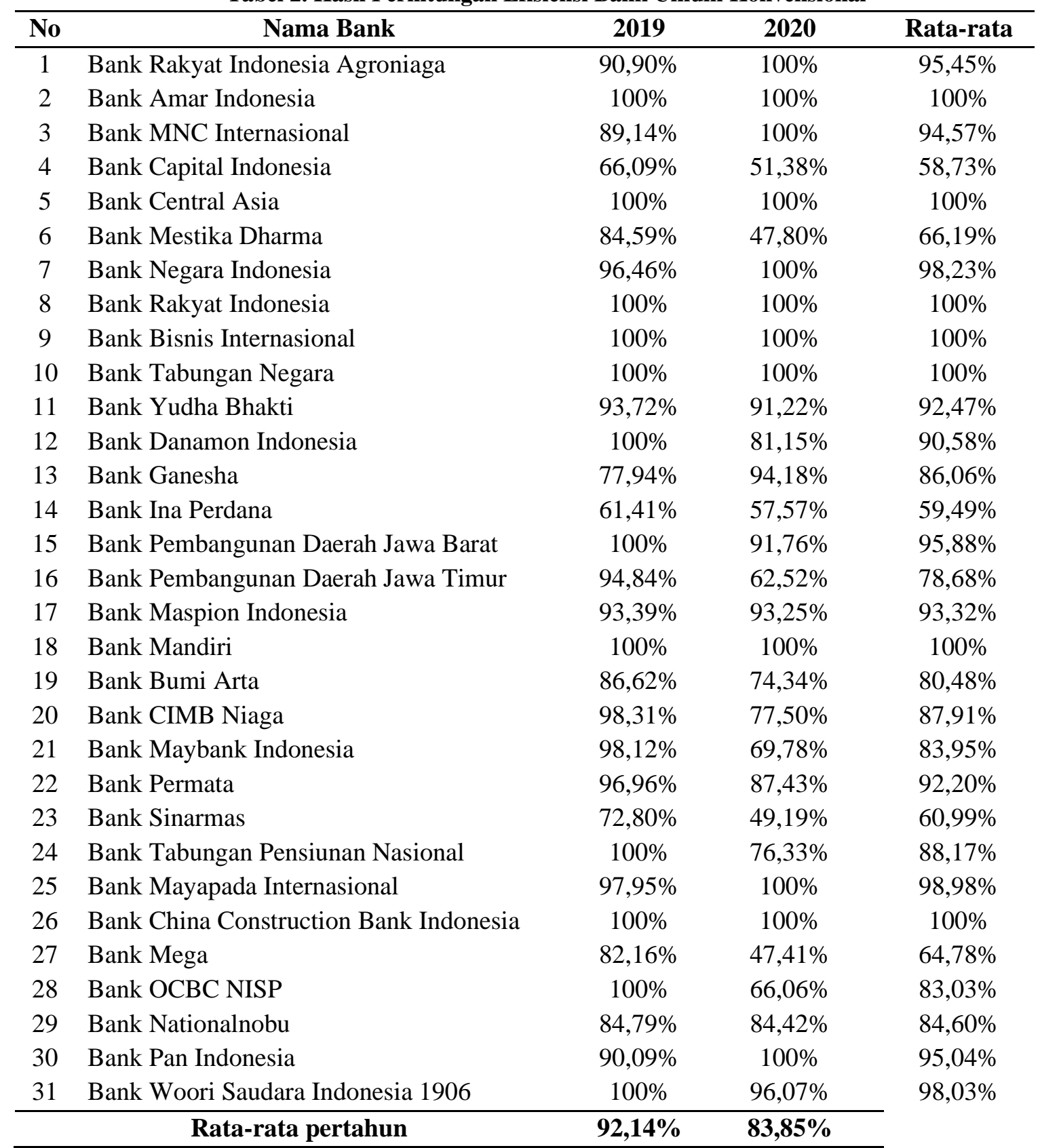

Sumber: data diolah, 2021

Berdasarkan tabel 2 di atas yang merupakan hasil perhitungan efisiensi Bank Umum Konvensional menunjukkan prosentase angka yang beragam. Bank dapat dinyatakan efisien, apabila menghasilkan nilai yang mengarah pada nilai 1 atau 100\%, kebalikannya apabila nilai mendekati 0 mengidentifikasi hasil adanya inefisiensi atau efisiensi bank yang kian rendah. 
Jurnal Riset Manajemen Sains Indonesia (JRMSI) | Vol 12, No. 2, 2021 e-ISSN: 2301-8313 http://doi.org/10.21009/JRMSI

Hasil perhitungan efisiensi tersebut menjelaskan bahwa nilai efisiensi kinerja keuangan dari 31 Bank Umum Konvensional yang menjadi sampel penelitian mengidentifikasi adanya beberapa bank dalam keadaan inefisiensi secara terus menerus yang berfluktuatif, terdapat bank dalam keadaan inefisiensi namun pernah pula menghasilkan nilai efisiensi $100 \%$ dan terdapat pula yang menghasilkan nilai efisiensi $100 \%$ dengan terus menerus semasa periode 2019-2020. Adapun perbankan yang menghasilkan nilai efisiensi 100\% dengan terus menerus semasa periode 2019-2020, yaitu Bank Amar Indonesia, Bank Central Asia, Bank Rakyat Indonesia, Bank Bisnis Internasional, Bank Tabungan Negara, Bank Mandiri dan Bank China Construction Bank Indonesia.

Tabel 3. Hasil Perhitungan Efisiensi Bank Umum Syariah

\begin{tabular}{|c|c|c|c|c|}
\hline No & Nama Bank & 2019 & 2020 & Rata-rata \\
\hline 1 & Bank Aceh Syariah & $100 \%$ & $100 \%$ & $100 \%$ \\
\hline 2 & BCA Syariah & $100 \%$ & $100 \%$ & $100 \%$ \\
\hline 3 & Bank Jabar Banten Syariah & $100 \%$ & $100 \%$ & $100 \%$ \\
\hline 4 & Bank Syariah Bukopin & $100 \%$ & $100 \%$ & $100 \%$ \\
\hline 5 & Bank Muamalat Indonesia & $100 \%$ & $100 \%$ & $100 \%$ \\
\hline 6 & Bank Mega Syariah & $100 \%$ & $67,23 \%$ & $83,61 \%$ \\
\hline 7 & Bank BNI Syariah & $100 \%$ & $100 \%$ & $100 \%$ \\
\hline 8 & Bank Net Indonesia Syariah & $100 \%$ & $100 \%$ & $100 \%$ \\
\hline 9 & Bank BRI Syariah & $47,01 \%$ & $47,73 \%$ & $47,37 \%$ \\
\hline 10 & Bank Syariah Mandiri & $100 \%$ & $100 \%$ & $100 \%$ \\
\hline 11 & Bank Tabungan Pensiunan Nasional Syariah & $100 \%$ & $100 \%$ & $100 \%$ \\
\hline 12 & BPD Nusa Tenggara Barat Syariah & $94,88 \%$ & $100 \%$ & $97,44 \%$ \\
\hline 13 & Bank Panin Dubai Syariah & $100 \%$ & $68,36 \%$ & $84,18 \%$ \\
\hline \multicolumn{2}{|r|}{ Rata-rata pertahun } & $\mathbf{9 5 , 5 3 \%}$ & $91,02 \%$ & \\
\hline
\end{tabular}

Hasil perhitungan efisiensi yang ditunjukkan pada tabel 3 tersebut menjelaskan bahwa nilai efisiensi kinerja keuangan dari 13 Bank Umum Syariah yang menjadi sampel penelitian mengidentifikasi adanya beberapa bank dalam keadaan inefisiensi secara terus menerus yang berfluktuatif, terdapat bank dalam keadaan inefisiensi namun pernah pula menghasilkan nilai efisiensi $100 \%$ dan terdapat pula yang menghasilkan nilai efisiensi $100 \%$ dengan terus menerus selama periode 2019-2020. Adapun perbankan yang menghasilkan nilai efisiensi 100\% dengan terus menerus, yaitu Bank Aceh Syariah, BCA Syariah, Bank Jabar Banten Syariah, Bank Syariah Bukopin, Bank Muamalat Indonesia, Bank BNI Syariah, Bank Net Indonesia Syariah, Bank Syariah Mandiri dan Bank Tabungan Pensiunan Nasional Syariah. 
Jurnal Riset Manajemen Sains Indonesia (JRMSI) | Vol 12, No. 2, 2021 e-ISSN: 2301-8313 http://doi.org/10.21009/JRMSI

Berlandaskan pada tabel hasil perhitungan efisiensi kinerja keuangan dari seluruh sektor perbankan tersebut di atas, dapat diketahui bahwa tingkat efisiensi Bank Umum Konvensional di tahun 2019 ada 12 Bank Umum Konvensional yang menyentuh nilai 100\% dengan rata-rata perolehan di tahun 2019 adalah 92,14\%. Sementara di tahun 2020 ada 12 Bank Umum Konvensional pula yang menyentuh nilai 100\%, namun rata-rata perolehan di tahun 2020 mengalami penurunan yaitu 83,85\%. Adapun penurunan ini sebesar 8,29\% dari tahun 2019. Di sisi lain, tingkat efisiensi Bank Umum Syariah di tahun 2019 dihasilkan 11 Bank Umum Syariah yang menyentuh nilai 100\% dengan rata-rata perolehan di tahun 2019 adalah 95,53\%. Sedangkan di tahun 2020 dihasilkan 10 Bank Umum Syariah yang menyentuh nilai $100 \%$, tetapi rata-rata perolehan di tahun 2020 merosot menjadi 91,02\%, dengan penurunan sebesar 4,51\% dari tahun 2019.

\section{Pembahasan}

Berdasarkan pada temuan hasil efisiensi kinerja keuangan sektor perbankan di Indonesia tersebut diketahui bahwa tingkat efisiensi sektor perbankan, baik Bank Umum Konvensional ataupun Bank Umum Syariah menghadapi penyusutan yang substansial di masa pandemi covid-19 ini. Hal tersebut dapat dilihat pada tingkat efisiensi perbankan di tahun 2020 pada masa covid-19 dengan tahun 2019 pada masa sebelum covid-19 mewabah di Indonesia. Kondisi pandemi covid-19 saat ini memberi imbas yang memprihatinkan pada kegiatan bisnis sektor perbankan, terutama dalam menciptakan efisiensi kinerja keuangan yang optimal bagi seluruh sektor perbankan di Indonesia.

Hasil pengukuran efisiensi tersebut menunjukkan bahwa adanya penyusutan tingkat efisiensi di masa pandemi covid-19 pada Bank Umum Syariah lebih stabil jika dibandingakn dengan tingkat efisiensi Bank Umum Konvensional. Hal ini dapat dilihat pada prosentase penurunan efisiensi pada Bank Umum Syariah yang mencapai 4,51\%, sedangkan Bank Umum Konvensional mencapai 8,29\% yaitu hampir dua kali lipat dari prosentase penurunan Bank Umum Syariah. Kondisi tersebut menandakan bahwa perbankan syariah di Indonesia cukup kuat dalam menghadapi pengaruh pandemi covid-19 saat ini.

Adapun beberapa perbankan yang berhasil meraih tingkat efisiensi yang optimal dengan nilai prosentase $100 \%$, dapat dianggap bahwasanya bank tersebut sanggup memaksimalkan sumber daya atau input yang ada demi mewujudkan output yang optimal. Maksudnya bahwa nilai input dan output yang dihasilkan oleh bank-bank yang efisien 
Jurnal Riset Manajemen Sains Indonesia (JRMSI) | Vol 12, No. 2, 2021 e-ISSN: 2301-8313 http://doi.org/10.21009/JRMSI

tersebut telah berhasil meraih tujuan yang diharapkan. Sedangkan bank-bank yang belum berhasil meraih tingkat efisiensi yang optimal diduga akibat adanya ketidaksanggupan bank dalam memaksimalkan sumber daya atau input yang ada demi mewujudkan output yang optimal. Selain itu, mulai mewabahnya pandemi covid-19 sejak Maret 2020, seluruh sektor menjadi perhatian besar bagi masyarakat Indonesia. Banyak kerugian yang muncul sebagai akibat dari adanya pandemi covid-19 yang berpengaruh terhadap perekonomian Indonesia secara umum. Begitupun yang dihadapi oleh sektor perbankan sebagai jantung perekonomian suatu negara.

Hasil penelitian ini sependapat dengan hasil riset yang telah dijalankan oleh Ningsih dan Mahfudz (2020) yang menyebutkan bahwa sejak pandemi covid-19 masuk ke Indonesia, semua perbankan syariah di Indonesia mengalami guncangan hebat yang berdampak pada penurunan penghimpunan dana dan pembiayaan.

\section{KESIMPULAN DAN SARAN}

Berdasarkan pengukuran efisiensi kinerja keuangan sektor perbankan di Indonesia, diperoleh hasil yang menunjukkan bahwa rata-rata tingkat efisiensi sektor perbankan baik Bank Umum Konvensional ataupun Bank Umum Syariah menghadapi penurunan yang substansial di masa pandemi covid-19 ini. Hal ini disebabkan karena menurunnya pendapatan dari penghimpunan dana dan penyaluran pembiayaan, sedangkan biaya operasional perbankan terus mengalami peningkatan untuk kebutuhan operasional harian perusahaan. Karena pada dasarnya keuntungan perbankan dihasilkan dari peran perbankan ketika menjadi perantara antara peminjam dan deposan dengan menggunakan keuntungan yang kompetitif dalam mengumpulkan informasi dan risiko penjaminan. Sehingga upaya perbaikan-perbaikan sektor perbankan masih terus diperlukan agar mencapai tingkat efisiensi yang optimal. Dalam situasi krisis yang diakibatkan pandemi covid-19, banyak kerugian yang muncul pada perekonomian nasional, terutama pada industri sektor keuangan. Adanya berbagai stimulus kebijakan yang dikeluarkan pemerintah untuk mengurangi timbulnya dampak negatif tersebut menjadikan rata-rata prosentase penurunan tingkat efisiensi sektor perbankan secara umum dapat dikendalikan.

Diharapkan manajemen perbankan terus melakukan evaluasi atas efisiensi kinerja keuangan sektor perbankan saat ini. Agar perbankan yang telah mencapai tingkat efisiensi maksimal $100 \%$ dapat mempertahankan tingkat efisiensinya, sedangkan perbankan yang 
Jurnal Riset Manajemen Sains Indonesia (JRMSI) | Vol 12, No. 2, 2021 e-ISSN: 2301-8313 http://doi.org/10.21009/JRMSI

masih mengalami inefisiensi diharapkan mampu meningkatkan kinerjanya lebih baik lagi untuk menghasilkan output yang maksimal, terkhusus di masa pandemi covid-19 ini. Hal tersebut sebagai upaya dan strategi perbankan agar dapat bertahan dalam lingkungan yang kompetitif.

Peneliti menyadari bahwa hasil penelitian ini masih jauh dari sempurna. Hasil penelitian ini masih memiliki keterbatasan yaitu adanya kelemahan pengukuran efisiensi dengan metode Data Envelopment Analysis (DEA) adalah pada penentuan variabel-variabel input dan output yang dipilih. Sehingga dalam penelitian mendatang diharapkan dapat menambah variabel penelitian dengan memperhatikan faktor-faktor lain dalam perbankan. Hal tersebut diharapkan agar hasil yang ditemukan akan jauh lebih baik.

\section{DAFTAR PUSTAKA}

Abdul-Wahab, A. H., \& Haron, R. (2017). Efficiency of Qatari banking industry: an empirical investigation. International Journal of Bank Marketing, 35(2), 298-318. https://doi.org/10.1108/IJBM-07-2016-0090

Adeabah, D., \& Andoh, C. (2020). Cost efficiency and welfare performance of banks: evidence from an emerging economy. International Journal of Managerial Finance, 16(5), 549-574. https://doi.org/10.1108/IJMF-06-2019-0212

Alam, N. (2013). Impact of banking regulation on risk and efficiency in Islamic banking. Journal of Financial Reporting and Accounting, 11(1), 29-50. https://doi.org/10.1108/jfra-03-2013-0010

Albanjari, F. R., \& Kurniawan, C. (2020). Implementasi Kebijakan Peraturan Otoritas Jasa Keuangan (POJK) No. 11/POJK. 03/2020 Dalam Menekan Non Performing Financing (NPF) Pada Perbankan Syariah. EKSYAR: Jurnal Ekonomi Syari'ah \& Bisnis Islam, 7(01), 24-36.

Alhassan, A. L., \& Ohene-Asare, K. (2016). Competition and bank efficiency in emerging markets: empirical evidence from Ghana. African Journal of Economic and Management Studies, 7(2), 268-288. https://doi.org/10.1108/AJEMS-01-2014-0007

Anagnostopoulos, I., Noikokyris, E., \& Giannopoulos, G. (2020). A meta-crisis banking efficiency study in the MENA region. Journal of Islamic Accounting and Business Research, 11(9), 2087-2112. https://doi.org/10.1108/JIABR-12-2019-0235

Andrieș, A. M., \& Ursu, S. G. (2016). Financial crisis and bank efficiency: An empirical study of European banks. Economic Research-Ekonomska Istrazivanja , 29(1), 485-497. https://doi.org/10.1080/1331677X.2016.1175725

http://journal.unj.ac.id/unj/index.php/jrmsi 
Jurnal Riset Manajemen Sains Indonesia (JRMSI) | Vol 12, No. 2, 2021 e-ISSN: 2301-8313 http://doi.org/10.21009/JRMSI

Arianto, B. (2021). Dampak Pandemi Covid-19 terhadap Perekonomian Dunia. Jurnal Ekonomi Perjuangan, 2(2), 106-126. https://doi.org/10.36423/jumper.v2i2.665

Arrawatia, R., Misra, A., \& Dawar, V. (2015). Bank competition and efficiency: Empirical evidence from Indian market. International Journal of Law and Management, 57(3), 217-231. https://doi.org/10.1108/IJLMA-03-2014-0029

Awaluddin, M., Mutmainna, A., \& Wardhani, R. S. (2019). Komparasi Efisiensi Penyaluran Kredit Pada Bank Umum Syariah (BUS) antara Bank Mega Syariah dan Bank CIMB Niaga Syariah Dengan Pendekatan Data Envelopment Analysis (DEA). Al-Mashrafiyah: Jurnal Ekonomi, Keuangan, Dan Perbankan Syariah, 3(2), 95. https://doi.org/10.24252/al-mashrafiyah.v3i2.9273

Azhari, A. R., \& Wahyudi, R. (2020). Analisis Kinerja Perbankan Syariah Di Indonesia: Studi Masa Pandemi Covid-19. Ekonomi Syariah Indonesia, X(2), 67-83.

Cabrera-Suárez, I., \& V. Pérez-Rodríguez, J. (2020). Assessing branch efficiency and managerial behaviour in a large Spanish commercial bank. Revista Espanola de $\begin{array}{llll}\text { Financiacion } & y & \text { Contabilidad, } & 49(1),\end{array}$ https://doi.org/10.1080/02102412.2018.1556878

Dara, S. R. (2017). Pengujian Efisiensi Perbankan Konvensional Di Indonesia Melalui Pendekatan Data Envelopment Analysis (Dea). Jurnal Riset Manajemen Dan Bisnis (JRMB) Fakultas Ekonomi UNIAT, 2(September), 251-260. https://doi.org/10.36226/jrmb.v2is 1.58

Dell'Atti, S., Pacelli, V., \& Mazzarelli, G. (2015). The efficiency of the European banking groups and its determinants. Managerial Finance, 41(7), 734-751. https://doi.org/10.1108/MF-12-2013-0335

Evandri Notalin, N. A., \& Asnaini. (2021). Dampak Covid-19 Terhadap Tingkat Efisiensi Kinerja Keuangan Bank Umum Syariah Di Indonesia Menggunakan Pendekatan Data Envelopment Analysis (Dea). Jurnal Ilmiah Akuntansi, 4(1), 169-178.

Eyceyurt Batir, T., Volkman, D. A., \& Gungor, B. (2017). Determinants of bank efficiency in Turkey: Participation banks versus conventional banks. Borsa Istanbul Review, 17(2), 86-96. https://doi.org/10.1016/j.bir.2017.02.003

Hanoatubun, S. (2020). Dampak Covid-19 terhadap Prekonomian Indonesia. EduPsyCouns: Journal of Education, Psychology and Counseling, 2(1), 146-153.

Henriques, I. C., Sobreiro, V. A., Kimura, H., \& Mariano, E. B. (2018). Efficiency in the Brazilian banking system using data envelopment analysis. Future Business Journal, 4(2), 157-178. https://doi.org/10.1016/j.fbj.2018.05.001

Himmawan, M. F., \& Firdausi, N. A. (2021). Projection of Indonesian Islamic commercial banks efficiency and stability in the Covid-19 period using DEA and panel ARDL. 
Jurnal Riset Manajemen Sains Indonesia (JRMSI) | Vol 12, No. 2, 2021 e-ISSN: 2301-8313 http://doi.org/10.21009/JRMSI

Jurnal Ekonomi \& Keuangan Islam, 7(1), 17-30. https://doi.org/10.20885/jeki.vol7.iss1.art2

Ikra, S. S., Rahman, M. A., Wanke, P., \& Azad, M. A. K. (2021). Islamic banking efficiency literature (2000-2020): a bibliometric analysis and research front mapping. International Journal of Islamic and Middle Eastern Finance and Management, ahead-of-p(ahead-ofprint). https://doi.org/10.1108/imefm-05-2020-0226

Kamarudin, F., Sufian, F., Loong, F. W., \& Anwar, N. A. M. (2017). Assessing the domestic and foreign Islamic banks efficiency: Insights from selected Southeast Asian countries. Future Business Journal, 3(1), 33-46. https://doi.org/10.1016/j.fbj.2017.01.005

Kamarudin, F., Sufian, F., \& Nassir, A. M. (2016). Does country governance foster revenue efficiency of Islamic and conventional banks in GCC countries? EuroMed Journal of Business.

Li, R., Li, L., \& Zou, P. (2021). Credit risk shocks and banking efficiency: a study based on a bootstrap-DEA model with nonperforming loans as bad output. Journal of Economic Studies, 48(1), 1-19. https://doi.org/10.1108/JES-08-2019-0395

Miftahurrohman. (2017). Analisis Faktor-Faktor yang Mempengaruhi Tingkat Efisiensi Perbankan Syariah dengan Pendekatan Data Envelopment Analysis (Studi pada Bank Syariah Negara-negara ASEAN). Jurnal Lentera Akuntansi, 71-91.

Mulazid, M. S. P. A. S. (2017). Analisis Efisiensi Bank Umum Syariah (BUS) di Indonesia dengan Menggunakan Metode Data Envelopment Analysis (DEA) Periode 2013-2015. Al-Mabsut: Jurnal Studi Islam Dan Sosial, 11(1), 111-128.

Neves, M. E. D., Gouveia, M. D. C., \& Proença, C. A. N. (2020). European Bank's Performance and Efficiency. Journal of Risk and Financial Management, 13(4), 67. https://doi.org/10.3390/jrfm13040067

Ngo, T., \& Le, T. (2019). Capital market development and bank efficiency: a cross-country analysis. International Journal of Managerial Finance, 15(4), 478-491. https://doi.org/10.1108/IJMF-02-2018-0048

Ningsih, M. R., \& Mahfudz, M. S. (2020). Dampak Pandemi Covid-19 Terhadap Manajemen Industri Perbankan Syariah: Analisis Komparatif. Point, 2(1), 1-10. https://doi.org/10.46918/point.v2i1.576

Othman, F. M., Mohd-Zamil, N. A., Rasid, S. Z. A., Vakilbashi, A., \& Mokhber, M. (2016). Data envelopment analysis: A tool of measuring efficiency in banking sector. International Journal of Economics and Financial Issues, 6(3), 911-916.

Puspitasari, A., Purnomo, D., \& Triyono, T. (2018). Penggunaan Data Envelopment Analysis (DEA) dalam Pengukuran Efisiensi Bank Umum Syari'ah di Indonesia. BISNIS : Jurnal Bisnis Dan Manajemen Islam, 5(2), 293. https://doi.org/10.21043/bisnis.v5i2.3015 
Jurnal Riset Manajemen Sains Indonesia (JRMSI) | Vol 12, No. 2, 2021 e-ISSN: 2301-8313 http://doi.org/10.21009/JRMSI

Puteh, A., Rasyidin, M., \& Mawaddah, N. (2018). Islamic banks in indonesia: Analysis of efficiency. Emerald Reach Proceedings Series, 1, 331-336. https://doi.org/10.1108/9781-78756-793-1-00062

Rahmi, H., \& Putri, D. Z. (2019). Analisis Efisiensi Perbankan Syariah Selama Krisis Global Di Indonesia. Jurnal Kajian Ekonomi Dan Pembangunan, 1(2), 321-330.

Řepková, I. (2015). Banking Efficiency Determinants in the Czech Banking Sector. Procedia Economics and Finance, 23(October 2014), 191-196. https://doi.org/10.1016/s22125671(15)00367-6

Roy, D. (2014). Analysis of Technical Efficiency of Indian Banking Sector. International Journal of Finance \& Banking Studies (2147-4486), 3(1), 150-160. https://doi.org/10.20525/ijfbs.v3i1.176

Sufian, F. (2011). Benchmarking the efficiency of the Korean banking sector: A DEA approach. Benchmarking, 18(1), 107-127. https://doi.org/10.1108/14635771111109841

Syairozi, M. I., \& Handayati, R. (2017). Analisis Efisiensi Perbankan Syariah (Unit Usaha Syariah) Indonesia Periode 2013-2015: Pendekatan Dea (Data Envelopment Analysis). Economic: Journal of Economic and Islamic Law, 8(2), 93-103.

Tahliani, H. (2020). Tantangan Perbankan Syariah dalam Menghadapi Pandemi Covid-19. Madani Syari'ah, 3(2), 92-113. https://stai-binamadani.ejournal.id/Madanisyariah/article/view/205

Titko, J., Stankevičienè, J., \& Lāce, N. (2014). Measuring bank efficiency: DEA application. Technological and Economic Development of Economy, 20(4), 739-757. https://doi.org/10.3846/20294913.2014.984255

Yilmaz, A., \& Güneş, N. (2015). Efficiency Comparison of Participation and Conventional Banking Sectors in Turkey between 2007-2013. Procedia - Social and Behavioral Sciences, 195, 383-392. https://doi.org/10.1016/j.sbspro.2015.06.338

Zenebe Lema, T. (2017). Determinants of bank technical efficiency: Evidence from commercial banks in Ethiopia. Cogent Business and Management, 4(1). https://doi.org/10.1080/23311975.2016.1268356

Zhao, Y., Chupradit, S., Hassan, M., Soudagar, S., Shoukry, A. M., \& Khader, J. (2021). The role of technical efficiency, market competition and risk in the banking performance in G20 countries. Business Process Management Journal. https://doi.org/10.1108/BPMJ12-2020-0570

Zheng, C., \& Zhang, J. (2020). Since January 2020 Elsevier has created a COVID-19 resource centre with free information in English and Mandarin on the novel coronavirus COVID- 19. The COVID-19 resource centre is hosted on Elsevier Connect, the company's public news and information. January. 
Jurnal Riset Manajemen Sains Indonesia (JRMSI) | Vol 12, No. 2, 2021 e-ISSN: 2301-8313 http://doi.org/10.21009/JRMSI

www.idx.co.id

www.ojk.go.id 